DOI 10.31718/2077-1096.20.2.50

УДК 618.2-056.5:616.1

\title{
Зелінка-Хобзей М. М.
}

\section{ЕНДОТЕЛІАЛЬНИЙ ФАКТОР РОСТУ СУДИН ЯК МАРКЕР ЕНДОТЕЛІАЛЬНОЇ ДИСФУНКЦІЇ У ВАГІТНИХ ЖІНОК ІЗ ОЖИРІННЯМ}

Українська медична стоматологічна академія, м. Полтава

На сьогодні ожиріння є одним з найпоширеніших у всьому світі захворювань і являється фактором ризику виникнення акушерських та перинатальних ускладнень. Саме тому метою дослідження $\epsilon$ визначення показників ендотеліального фрактору росту судин у сироватці крові вагітних жінок з фрізіологічною масою тіла та при ожирінні різного ступеня в I та III mриместрах вагітності. Maтеріали і методи. Для проведення дослідження нами було сорормовано 6 груп. Першу групу (контрольну) склали вагітні жінки із фрізіологічною масою тіла у I триместрі; друга група - вагітні жінки із фрізіологічною масою тіла у III триместрі; третя група - вагітні жінки із ожирінням I ступеня у I триместрі (по 20 жінок у кожній групі); четверта група - вагітні жінки із ожирінням I ступеня у ІІІ триместрі (15 жінок); п'ята група - вагітні жінки із ожирінням II та III ступеня у I триместрі (20 жінок); шоста група - вагітні жінки із ожирінням II та III ступеня у III триместрі (15 жінок). Результати дослідження та їх обговорення. У cmammi наведена оцінка показників ангіогенезу у вагітних із фізіологічною масою тіла та у вагітних із супутнім ожирінням. Резюмуючи отримані результати, спостерігалась закономірність зниження даного ангіогенного фрактору у сироватиі крові у міру зростання ожиріння у I та III триместрах вагітності. Одержані показники ендотеліального фактору росту судин у I триместрі дають можливість прогнозування виникнення акушерських ускладнень у вагітних жінок із ожирінням. Висновки: 1. Ендотеліальний фактору росту судин у сироватці крові вагітних з фізіологічною масою тіла зростає у міру прогресування вагітності. 2. Концентрація фрактору росту ендотелію судин у сироватці крові вагітних з супутнім ожиріння у I та III mриместрах вагітності закономірно знижується відповідно до зростання тяжкості ожиріння, а його показники у вагітних жінок із ожирінням в I триместрі можуть бути використаними для прогнозування виникнення акушерських ускладнень пов'язаних із ожирінням.

Ключові слова: ендотеліальна дисфункція, VEGF, вагітність, ожиріння, акушерські ускладнення.

Робота входить до науково-дослідної роботи кафедри акушерства і гінекології №1: «Патогенетична роль ендотеліальної дисфункції та генетичні особливості при патології під час вагітності та гінекологічних захворюваннях», № державної реєстраціï 0117 U005253.

\section{Вступ}

Ожиріння $є$ одним з найпоширеніших у всьому світі захворювань. Згідно з даними Всесвітньої організації охорони здоров'я, більше $23 \%$ чоловіків і $25 \%$ жінок мають надлишкову масу тіла. На сьогодні ожиріння $є$ проблемою багатьох жителів не лише нашої держави, але і усієї планети. В Україні від зайвої маси страждає кожна четверта жінка і кожен шостий чоловік. Ожиріння являється фактором ризику виникнення акушерських та перинатальних ускладнень, таких як: прееклампсія, дисфункція плаценти, акушерські кровотечі, дистрес плоду, передчасних пологів та інші [1, 2].

У зв'язку з високим рівнем ускладнень під час вагітності, пологів, у післяпологовому періоді у жінок з супутнім ожирінням останнім часом багато уваги приділяється вивченню особливостей метаболічних процесів та стану ендотелію, які $\epsilon$ основою функціонування системи мати - плацента - плід.

У пацієнток із ожирінням васкулярні порушення та гемодинамічні зміни можуть розвиватися дуже рано і тим самим підвищувати ризик розвитку захворювань пов'язаних з ендотеліальною дисфункцією [3]. Основна мета ендотеліальної регуляції - підтримання динамічної рівноваги різноспрямованих процесів вазоконстрикції і вазодилатації, тромбоутворення і фібринолізу, синтезу і пригнічення фракторів проліфера- ції, прозапальної і протизапальної активності.

Жирова тканина хворих на ожиріння збільшує продукцію прозапальних білків, які мають прямий вплив на метаболізм. Одним із пояснень зв'язку ожиріння і тяжкої прееклампсії, що є одною із частих проявів ендотеліальної дисфункції при вагітності, являються відхилення в метаболізмі ліпідів. Уже в ранні терміни вагітності при ожирінні має місце гіперліпідемія, яка сприяє перекисному окисленню ліпідів з порушенням балансу вазоактивних компонентів та провокуванням дисфункції ендотелію і вазоконстрикції, які, як відомо, $€$ основними ланками патогенезу прееклампсії $[4,5,6]$.

За даними багатьох авторів, правильне формування матково-плацентарного кровотоку відбувається за рахунок гестаційної перебудови спіральних артерій, що полягає у заміщенні ендотелію ендометріальних і міометріальних відділів клітинами трофобласта таким чином, що спіральні артерії втрачають свій м'язовоеластичний компонент і перетворюються в дилатовані судини з постійним кровотоком $[7,8]$.

3 настанням вагітності спіральні артеріоли матки, по яких надходить кров до плоду, що розвивається, коротшають та розширюються в міру підвищення метаболічних потреб плода. При вагітності, ускладненій ендотеліальною дисфункцією, ці зміни судинного руслу матки не відповідають зростанню плода, інтенсивність кровотоку 
сповільнюється, плід відчуває ішемію і гіпоксію. При чому ці зміни зберігаються протягом всієї вагітності і не залежать від терміну вагітності [9].

Інсулінорезистентність, як ще одна із складових ожиріння, також впливає на еластичність стінок артерій, розвиток ендотеліальної дисфрункції та підвищення тромбоутворення $[10,11]$.

Отже, такі основні патогенетичні риси ожиріння, як глюкозотоксичнісь, ліпотоксичність та хронічний прозапальний статус, відіграють важливу роль в розвитку ендотеліальної дисфункції.

Наразі великого значення набуло вивчення продукції судинно-ендотеліального фактора росту - (VEGF) у зв'язку з його принциповим впливом у розвитку вагітності, адже сімейство VEGF відіграє важливу роль у фрізіологічному рості плаценти, судинної системи строми ворсин і базальної пластинки, а також регулює інвазію цитотрофобласта, що необхідно для нормальної трансформації спіральних артерій і розвитку повноцінного матково-плацентарного кровотоку, оскільки запорукою благоприємного перебігу вагітності $€$ адекватне кровопостачання фетоплацентарного комплексу [12].

VEGF (Vascular endothelial growth factor) - сигнальний білок, що виробляється клітинами для стимулювання процесів васкулогенезу (утворення ембріональної судинної системи) і ангіогенезу (зростання нових судин у вже існуючій судинній системі). Фактор росту судинного ендотелію відомий також як білок, що індукується гіпоксією та виявляє властивості мітогена ендотеліоцитів та сприяє їх виживанню.

Зміни показників маркерів ангіогенезу, за даними сучасних дослідників, демонструють суттєве зниження концентрації VEGF у сироватці крові вагітних із прееклампсією. Адже прееклампсія вважається антиангіогенним станом, асоційованим із надлишковим потраплянням у кровотік білка sFIt 1, який являється антагоністом VEGF. Надлишок sFIt 1 у материнській крові призводить до зменшення вільного рівня циркулюючого VEGF, що в подальшому знижує його сприятливі ефекти на ендотелії і проявляється гіпертензією та протеїнурією [13, 14].

Адаптація маткового кровотоку до зростаючих потреб плода проходить за допомогою неоангіогенезу. VEGF збільшує область трофобласта і судин більше ніж у 2 рази, що призводить до збільшення площі поверхні обміну плодової частини плаценти. Зважаючи на те, що VEGF являється сильним стимулятором росту судин, які беруть участь у формуванні нормального плацентарного кровообігу, за даними деяких дослідників, вміст VEGF у сироватці крові знижується не лише при прееклампсії, але і при таких ускладненнях вагітності, як синдром внутрішньоутробної затримки росту плода та при фетоплацентарній недостатності. Ймовірність розвитку того чи іншого ускладнення вагітності залежить від швидкості розвитку дисбалансу і компенсаторно-пристосувальних можливостей плоду та материнського організму.

Прогнозування ризику розвитку акушерських ускладнень, пов'язаних з ендотеліальною дисфункцією найбільш важливе в ранні терміни вагітності, оскільки дає можливість для своєчасного початку проведення профілактичних заходів $[15,16]$.

У літературі наведені дані, що маса тіла може впливати на показники VEGF, а також отримані результати даного фактору росту у вагітних із ожирінням та метаболічним синдромом, оскільки на фоні ожиріння формування плацент проходить 3 порушенням процесів ангіонеогенезу, що проявляються зменшенням розгалуження судин і зниженням васкуляризації ворсин. Ступінь вираженості цих змін корелює із степенем ожиріння і частотою розвитку акушерських ускладнень $[17,18]$, однак також доведено, що показники VEGF зростають у хворих на цукровий діабет та при ішемії нижніх кінцівок. Отже, все ж таки залишається актуальною оцінка VEGF у вагітних жінок із ожирінням з метою прогнозування акушерських ускладнень, пов'язаних з ендотеліальною дисфункцією.

Для підвищення точності прогнозу проявів та прогресування ендотеліальної дисфункції, окрім клінічних особливостей $є$ необхідною оцінка факторів, які б відображали ключові ланки патогенезу (хронічна матково-плацентарна ішемія, антиангіогенний та прозапальний дисбаланс), саме тому VEGF був обраним в якості критерія оцінки вираженості ендотеліальної дисфункції.

\section{Мета}

Дослідити показники фактору росту ендотелію судин у сироватці крові вагітних жінок з фрізіологічною масою тіла та при ожирінні різного ступеня в I та III триместрах вагітності.

\section{Матеріали і методи}

Для досягнення поставленої мети дослідження нами було сформовано 6 досліджуваних груп. У якості критерію включення використовувався показник індексу маси тіла (IMT), одноплідна вагітність та термін вагітності. Ступінь ожиріння вагітних розраховували за росто-ваговими параметрами з урахуванням терміну вагітності та віку жінок, згідно таблиці, запропонованої Н. С. Луценко. Задіяні для обстеження жінки надали письмову інформовану згоду пацієнта. Забір крові для дослідження було проведено на базах жіночих консультацій та акушерських відділень міста Полтави.

Першу групу (контрольну) склали вагітні жінки із фрізіологічною масою тіла (тобто IMT коливався в межах 18,5-24,9) у I триместрі; друга група - вагітні жінки із фрізіологічною масою тіла у III триместрі; третя група - вагітні жінки із ожирінням I ступеня (IMT від 30 до 34,9) у I триместрі (по 20 жінок у кожній групі); четверта група вагітні жінки із ожирінням I ступеня у III триместрі (15 жінок); п'ята група - вагітні жінки із ожирін-

Том 20, Випуск 2 (70) 
ням II та III ступеня (IMT 35 і більше) у I триместрі (20 жінок); шоста група - вагітні жінки із ожирінням II та III ступеня у III триместрі (15 жінок).

Досліджуваним жінкам проводили забір венозної крові з кубітальної вени натщесерце, відстоювали до утворення щільного згортка i центрифугували; отриману сироватку (об'ємом 1,5 мл) у стерильній пробірці типу «Еппендорф» зберігали при температурі $-20^{\circ} \mathrm{C}$ та визначали концентрацію VEGF у сироватці крові за допомогою набору «Вектор-Бест» (Росія) використовуючи метод твердофазного імуноферментного аналізу, згідно інструкції виробника.

Кількісні дані, представлені у вигляді середнього квадратичного відхилення і його стандартної похибки $(\mathrm{M} \pm \mathrm{m})$. Статистичне опрацювання результатів дослідження проводилось із застосуванням пакета програм «Statistica 6,0» (StatSoftInc., США) з використанням стандартних методів варіаційної статистики та критерію Стьюдента. Різницю вважали статистично значущою при $p<0,05$.

\section{Результати та обговорення}

Аналізуючи одержані показники концентрації VEGF у сироватці крові в I триместрі вагітності відмічається їх зниження в 2,0 рази у вагітних із ожирінням II-III ступенів $(p<0,05)$ та у 1,3 рази нижче у вагітних із ожирінням І ступеня $(p<0,05)$ порівнюючи із показниками у вагітних із фрізіологічною масою тіла (динаміка змін показників VEGF відображена в таблиці 1).

Таке значне зниження синтезу цього ангіогенного фактора росту у ранньому терміні вагітності може свідчити про початковий етап порушень у системі васкулогенезу та ангіогенезу, що робить свій внесок у розвиток системної ендотеліальної дисфункції. Враховуючи, що ці зміни спостерігаються у вагітних жінок із ожирінням, це може свідчити про більшу схильність цих пацієнток до подальшого виникнення та прогресування патологічних станів асоційованих з дисфункцією ендотелію.

Середні значення показників концентрації VEGF (пе/мл) у сироватці крові вааітних жінок при ожирінні

\begin{tabular}{|c|c|c|c|}
\hline Термін & Вагітні із фізіологічною масою тіла & Вагітні із ожирінням I ступеня & Вагітні із ожирінням II-III ступеня \\
\hline $\begin{array}{l}\text { I } \\
\text { триместр }\end{array}$ & $\begin{array}{c}364,54 \pm 35,34 \\
(20)\end{array}$ & $\begin{array}{c}283,37 \pm 27,26 \\
(20)\end{array}$ & $\begin{array}{c}182,27 \pm 11,86 \\
(20)\end{array}$ \\
\hline $\begin{array}{l}\text { III } \\
\text { триместр }\end{array}$ & $\begin{array}{l}492,75 \pm 40,29 \\
(20)\end{array}$ & $\begin{array}{c}212,22 \pm 27,38 \\
(15)\end{array}$ & $\begin{array}{c}125,00 \pm 16,19 \\
(15)\end{array}$ \\
\hline
\end{tabular}

На наступному етапі дослідження, а саме у III триместрі, у вагітних із фрізіологічною масою тіла відмічається зростання показників VEGF у сироватці крові в 1,4 рази у порівнянні із ранніми термінами вагітності $(p<0,05)$ (табл. 1). Це може бути обумовлено посиленим розвитком ворсинчастого дерева плаценти, судинної системи матки і збільшеним об'ємом крові, яка протікає через матку в III триместрі вагітності за умови їі нормального перебігу [19].

На відміну від зростаючих показників при фізіологічному перебігу вагітності, у вагітних жінок із супутнім ожирінням спостерігалось зниження концентрації VEGF у сироватці крові по мірі прогресування ступеня ожиріння, порівнюючи показники I та III триместрів вагітності (табл. 1). Зіставляючи середнє значення VEGF у сироватці крові вагітних III триместру, виявлено зниження цього показника в 2,3 рази у вагітних із ожирінням І ступеня $(p<0,05)$ та у 3,9 рази у вагітних із ожирінням II-III ступенів порівнюючи із показниками у вагітних із фрізіологічною масою тіла $(\mathrm{p}<0,05)$ (табл. 1).

Зниження сироваткового показника фактору росту ендотелію судин може вказувати на недостатність розвитку судинного русла, яка у свою чергу посилює ефекти вазоконстрикції в судинах як ворсинчатого хоріону плаценти так і плоду. Переважання вазоконстрикторних ендотеліальних факторів зумовлює звуження судин, гіпоксію, порушення трофіки тканин.

Резюмуючи отримані результати, спостерігається залежність показників фактору росту ен- дотелію судин у сироватці крові від терміну вагітності та IMT.

\section{Висновки}

1. Ангіогенний фрактор росту ендотелію судин у сироватці крові вагітних з фрізіологічною масою тіла зростає у міру прогресування вагітності.

2. Концентрація фактору росту ендотелію судин у сироватці крові вагітних з наявним ожиріння у I та III триместрах вагітності закономірно знижується у міру зростання IMT.

\section{Перспективи подальших досліджень}

Залишається доцільним подальше вивчення судинно-ендотеліального фактора росту у вагітних жінок із ожирінням з метою прогнозування акушерських ускладнень, пов'язаних з ендотеліальною дисфункцією та винайдення дієвих заходів спрямованих на запобігання її виникнення.

\section{Література}

1. Stevens $W$, Shih $T$, Incerti $D$, et al. Short-term costs of preeclampsia to the United States health care system. Am. J. Obstet. Gynecol. 2017 Sep;217(3):237-48. doi: 10.1016/j.ajog.2017.04.032.

2. Zhabchenko IA, Siudmak OR, Kovalenko TM. Ozhyrinnia u zhinky yak prychyna reproduktyvnykh problem. Zdorov'ye
zhenshchiny.[Obesity in women as a cause of reproductive zhenshchiny.[Obesity in women as a cau
problems]. 2017;10(126):34-8. (Ukrainian).

3. Chabanova NB, Mataev SI, Vasil'kova TN, i dr. Rol' sistemnogo vospalenija $v$ razvitii oslozhnenij beremennosti u zhenshhin $s$ ozhireniem. [The role of systemic inflammation in the development of pregnancy complications in obese women]. Akusherstvo ginekologija $\quad 2017 \cdot 10: 12-7 \quad$ Available from: https://dx.doi.org/10.18565/aig.2017.10.12-18.

4. Medvedev BI, Sjundjukova EG, Sashenkov SL. Klinikobiohimicheskie prediktory razvitija prejeklampsii. [Clinical and biochemical predictors of preeclampsia]. Akusherstvo i ginekologija. 2013;5:30-5. (Russian). 
5. Sjundjukova EG. Pokozateli sistemy gemostaza i lipidnogo profilja $\mathrm{u}$ beremennyh $\mathrm{s}$ preeklampsiej. [Indicators of the hemostatic system and lipid profile in pregnant women with preeclampsia]. Vrach-aspirant. 2015.2:14-21. Available https://dx.doi.org/10.18565/aig.2017.10.12-18. (Russian)

6. Hopchuk OM. Mozhlyvosti vykorystannia L-arhininu $v$ akusherstvi ta hinekolohii dlia likuvannia patolohii, sprychynenykh endotelialnoiu dysfunktsiieiu. [Possibilities of using L-arginine in obstetrics and gynecology for the treatment of pathologies caused by endothelial dysfunction]. Zdorov'ye zhenshchiny. 2017; 2(118):50-4. (Ukrainian).

7. Likhachov VK, Dobrovolska LM, Taranovska OO, ta in. Stan pre platsentarnoho krovotoku yak predyktor rozvytku preeklampsii u zhinok $z$ khronichnym endometrytom $v$ anamnezi. [Preplacental blood flow as a predictor of preeclampsia in women with a history of chronic endometritis]. Science, Education and Culture in Eurasia and Africa. The 6th International Academic Congress. France, Paris, March 23-25, 2016. Paris:2016, p.551-7.

8. EreminaV, Quaggin SE. The role of VEGF-A in glomerular development and function. Curr. Opin. Nephrol. Hypertens. 2014; 13(1):9-15

9. Dhariwal NK, Lynde GC. Update in the Management of Patients with Preeclampsia. Anesthesiol Clin. 2017;35(1):95-106. DOI: 10.1016/j.anclin.2016.09.009.

10. Aganezova NV, Aganezov SS. Ozhirenie i reproduktivnoe zdorov'e zhenshhiny. [Obesity and reproductive health of women]. Akusherstvo i ginekologija. 2016;6:18-25. Available from: https://dx.doi.org/10.18565/aig.2016.6.18-25

11. Tarasenko KV, Mamontova TV, Vesnina LE. Vzaimosvjazi insulinorezistentnosti i giperinsulinemii s markerami sistemnogo vospalenija $u$ beremennyh zhenshhin $s$ ozhireniem razlichnoj stepeni. Ohrana materinstva i detstva. The relationship of insulin resistance and hyperinsulinemia with markers of systemic resistance and hyperinsulinemia with markers of systemic
inflammation in pregnant women with obesity of varying degrees]. 2014;2(24):48-51. (Russian).

12. Dyndar OA, Beniuk VO, Nykoniuk TR. Prohnozuvannia perynatalnykh uskladnen u zhinok iz ozhyrinniam i metabolichnym syndromom. [Prediction of perinatal acceleration in women with obesity and metabolic syndrome]. Zdorov'ye zhenshchiny. 2016;4(110):163-7. (Ukrainian).

13. Veropotveljan PN, Radchenko VV Cehmistrenko IS i dr. Problema prejeklampsii daleka ot svoego reshenija. [The problem of preeclampsia is far from being resolved]. Zdorov'ye of preeclampsia is far from
zhenshchiny. 2017;1(117):25-30.

14. Jakovleva NJu, Hazova EL, Vasil'evaEJu, Zazerskaja IE. Sootnoshenie angiogennyh i antiangiogennogo faktorov pri prejeklampsii. The ratio of angiogenic and antiangiogenic factors in preeclampsia]. Original'naja stat'ja. Original article. in preeclampsia]. (Russian)

15. Rolnik DL, Wright $D$, Poon LC, et al. Aspirin versus placebo in pregnancies at risk for preterm preeclampsia. N. Engl. J. Med. 2017;377(7):613-22. doi: 10.1056/NEJMoa1704559.

16. Holin AM, Hodzhaeva ZS, Gus AI. Trehmernaja jenergeticheskaja doplerovskaja ocenka vaskuljarizacii placentarnogo lozha $\mathrm{V}$
prognozirovanii prejeklampsii $\mathrm{V}$ pervom trimestre. [Threeprognozirovanii prejeklampsii $v$ pervom trimestre. [Three-
dimensional energy Doppler assessment of the vascularization of dimensional energy Doppler assessment of the vascularization of
the placental bed in predicting preeclampsia in the first trimester]. the placental bed in predicting preeclampsia in the first trimester].
Akusherstvo Akusherstvo i $\quad$ ginekologija.
doi:10.18565/aiq.2018.2.36-43.

17. Levakov SA, Borovkova El, Shhegolev Al, i dr. Klinikolaboratornye zakonomernosti techenija beremennosti na fone ozhirenija i metabolicheskogo sindroma. [Clinical and laboratory patterns of pregnancy during obesity and metabolic syndrome] Arhiv akusherstva i ginekologii im. V. F. Snegireva. 2014;2:19-25 (Russian)

18. Dyndar OA, Nykoniuk TR. Diahnostychni determinanty funktsionalnoho stanu fetoplatsentarnoho kompleksu u vahitnykh iz ozhyrinniam i metabolichnym syndromom. [ Diagnostic iz ozminants of the functional camp of the fetoplacental complex of the fetoplacental complex in most of the obese and metabolic syndrome]. Zdorov'ye zhenshchiny. 2016;2(108):90-4. (Ukrainian).

19. Strizhakov AN, Ignatko IV, Timohina EV, Belocerkovceva LD Sindrom zaderzhki rosta ploda. Patogenez. Diagnostika. Lechenie. Akusherskaja taktika. [Fetal growth retardation syndrome Pathogenesis. Diagnosis. Treatment. Obstetric tactics.] Moskva; 2014. $120 \mathrm{p}$. Available from: https://www.rosmedlib.ru/book/ISBN9785970431566.html.

\section{Рефрерат}

ЭНДОТЕЛИАЛЬНИЙ ФАКТОР РОСТА СОСУДОВ КАК МАРКЕР ЭНДОТЕЛИАЛЬНОЙ ДИСФУНКЦИИ У БЕРЕМЕННЫХ ЖЕНЩИН С ОЖИРЕНИЕМ

Зелинка-Хобзей М.Н.

Ключевые слова: эндотелиальная дисфункция, VEGF, беременность, ожирение, акушерские осложнения.

На сегодня ожирение - одно из самих распространенных заболеваний во всем мире и является фактором риска возникновения акушерских и перинатальных осложнений. Целью нашего исследования является определение показателей эндотелиального фактора роста сосудов в сыворотке крови беременных женщин с физиологической массой тела и при ожирении различной степени в I и III триместрах беременности. Материалы и методы. Для проведения исследования нами было сформировано 6 групп. Первую группу (контрольную) составили беременные женщины с физиологической массой тела в первом триместре; вторая группа - беременные женщины с физиологической массой тела в III триместре; третья группа - беременные женщины с ожирением I степени в I триместре (по 20 женщин в каждой группе) четвертая группа - беременные женщины с ожирением I степени в III триместpe (15 женщин); пятая группа - беременные женщины с ожирением II и III степени в I триместре (20 женщин); шестая группа - беременные женщины с ожирением II и III степени в III триместре (15 женщин). Результаты исследования и их обсуждение. В статье приведена оценка показателей ангиогенеза у беременных с физиологической массой тела и у беременных с сопутствующим ожирением. Резюмируя полученные результаты, наблюдалась закономерность снижения данного ангиогенного фактора в сыворотке крови по мере прогрессирования ожирения в I и III триместрах беременности. Полученные показатели эндотелиального фактора роста сосудов в I триместре дают возможность прогнозирования возникновения преэклампии у беременных женщин с ожирением. Выводы: 1. Эндотелиальный фрактор роста сосудов в сыворотке крови беременных с фризиологической массой тела растет в зависимости от срока беременности. 2. Концентрация эндотелиального фрактора роста сосудов в сыворотке крови беременных с сопутствующим ожирением в I и III триместрах беременности закономерно снижается в соответствии с ростом тяжести ожирения, а его показатели у беременных женщин с ожирением в I триместре могут быть использованы для прогнозирования возникновения акушерских осложнений, связанных с ожирением.

\section{Summary}

VASCULAR ENDOTHELIAL GROWTH FACTOR AS A MARKER OF ENDOTHELIAL DYSFUNCTION IN THE PREGNANT WOMEN WITH OBESITY

Zelinka-Khobzey M.M.

Key words: endothelial dysfunction, VEGF, pregnancy, obesity, obstetric complications.

Today, obesity is one of the most common diseases worldwide and is a risk factor for obstetric and perinatal complications. Therefore, the purpose of the study is to determine the vascular endothelial growth 
factor in the blood serum of pregnant women with physiological body weight and obesity of varying degrees in the first and third trimesters of gestation. Materials and methods. The subjects were divided into 6 groups. The first group (control) consisted of pregnant women with physiological body weight in the first trimester; the second group included pregnant women with physiological body weight in the third trimester; the third group involved pregnant women with obesity Class I in the first trimester ( 20 women in each group); the fourth group - pregnant women with obesity of Class I in the third trimester (15 women); the fifth group - pregnant women with obesity of Classes II - III in 1st trimester (20 women); the sixth group - pregnant women with obesity of Classes II - III in the third trimester (15 women). Results and discussion. The article presents the evaluation of angiogenesis in pregnant women with physiological body weight and in pregnant women with concomitant obesity. The analysis of the results obtained has demonstrated the following pattern: the blood serum angiogenic factor decreases as obesity increases over I and III trimesters. Conclusions: 1. The endothelial growth factor of blood vessels in pregnant women with physiological body weight increases as pregnancy progresses. 2. Concentration of vascular endothelial growth factor in the serum of pregnant women with concomitant obesity in the 1st and 3rd trimesters of pregnancy naturally decreases with increasing severity of obesity, and its indicators in pregnant women with obesity in the 1st trimester can be used to predict the occurrence of obstetric complications associated with obesity.

DOI 10.31718/2077-1096.20.2.54

УДК: 616.441-006.5-089-037

Ковальов О. П., Ляховський В. І., Люлька О. М., Нємченко І. І., Сидоренко А. В. ВАРІАНТИ ХІРУРГІЧНОЇ ТЕХНІКИ ПРИ ОПЕРАТИВНОМУ ЛІКУВАННІ ЗОБУ

Українська медична стоматологічна академія, м. Полтава

Проаналізовано характер 552 оперативних втручань з приводу різних форм зобу, виконаних у хірургічному відділенні на клінічній базі кафедри хірургії №1 Української медичної стоматологічної академії (м. Полтава). Жінок було 491 (їх частка склала 88,9\%), чоловіків - 61 (11,1\%). Дифузний токсичний зоб спостерігався у $48(8,7 \%)$, тиреотоксична аденома мала місце у $8(1,5 \%)$, однобічний вузловий зоб - у $162(29,3 \%)$, багатовузловий - у $334(60,4 \%)$ хворих. 3 приводу рецидивного зобу оперовані 20 (3,6\%) пацієнтів. Наведені методика екстрафрасціальної тиреоїдектомії та ії варіанти в залежності від форми, розміру зобу та його розташування. Запропоновані оригінальні методики по запобіганню ушкодження гортанних нервів та прищитоподібних залоз, які з успіхом використовуються при нестандартних операційних ситуаціях, а також спосіб мобілізації частки щитоподібної залози при шийно-позагрудинній локалізації зобу. Великі розміри зобу, злуковий процес, шийнопозагрудинне розташування щитоподібних залоз створюють незвичайну операційну ситуацію $і$ часто потребують нестандартних хірургічних підходів. Виникнення ускладнень під час виконання оперативних втручань уникали шляхом застосування екстрафрасціальної методики маніпуляцій по видаленню щитоподібної залози, застосуванню надійного контрольованого гемостазу та прецизійної техніки по ходу операції. Особлива небезпека виникає при недостатньо контрольованому гемостазі, який виникає по ходу операції. Основним у запобіганні специфрічних інтраопераційних ускладнень при операціях на щитоподібній залозі є свідоме поєднання новітніх технологій і досвіду хірурга. Післяопераційний транзиторний гіпопаратиреоз на 7-8 добу спостерігали у $9(1,6 \%)$ хворих з нормалізацією клінічних проявів і рівня кальцію, а у $6(1,1 \%)$ - осиплість та послаблення голосу протягом 3 тижнів. Більшість цих ускладнень трапилися у першу половину періоду, який було аналізовано. Дані варіанти виконання операції при складних операційних ситуаціях дозволили покращити результати хірургічного лікування.

Ключові слова: щитоподібна залоза, зоб, операції, хірургічна техніка.

Матеріали даної статmі є частиною науково-дослідної роботи "Розробка сучасних науково обґрунтованих принципів стратифрікації, моніторингу і прогнозування перебігу хірургічних захворювань та травм” (№ держреєстрації 0120U101176)

\section{Вступ}

Хірургічне лікування зобу відноситься до тієї сфери хірургічної діяльності, яка потребує постійного аналізу та пошуку оптимального вирішення різноманітних проблем, пов'язаних з особливостями методики, техніки та характеру оперативних втручань $[1,2,3,4]$.

Враховуючи велику кількість операцій в Україні з приводу різних форм зобу та інших вогнищевих процесів щитоподібної залози (ЩЗ) та їх постійне зростання, розробка ефективних методик оперативного лікування цієї патології є акту- альним і соціально значимим завданням $[5,6]$.

Багато робіт присвячено особливостям оперативної техніки по запобіганню специфічних ускладнень - ушкодженню так званих «структур ризику»: гортанних нервів та паращитоподібних залоз, а також проблемам косметичного характеру, враховуючи, що більшість хворих цією патологією - жінки $[7,8]$.

Значну роль в запобіганні післяопераційних ускладнень різного ґенезу і тяжкості відіграє адекватне передопераційне обстеження з використанням сучасних засобів діагностики, впровадження анатомічно орієнтованої прецизійної 